\title{
Chan-Yu-Bao-Yuan-Tang and 5-fluorouracil synergistically induce apoptosis by means of the caspase-3 signaling pathway in lung and cervical cancer cells
}

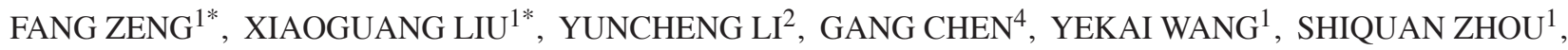 \\ WANGYU ZHU ${ }^{1}$, YANYAN HUANG ${ }^{1}$, JIEHANG ZHOU ${ }^{1}$, SHIBO LI $^{2}$ and YONGKUI ZHANG ${ }^{1,3}$ \\ ${ }^{1}$ Joint Laboratory of Immunogenomics, Zhoushan Hospital - Beijing Institute of Genomics, Chinese Academy of Sciences; \\ Departments of ${ }^{2}$ Infectious Diseases, and ${ }^{3}$ Cardiothoracic Surgery, Zhoushan Hospital, Zhoushan, Zhejiang 316004; \\ ${ }^{4}$ Experiment Center of TCM, Hubei University of Chinese Medicine, Wuhan 430065, P.R. China
}

Received June 18, 2010; Accepted October 18, 2010

DOI: $10.3892 / \mathrm{mmr} .2010 .388$

\begin{abstract}
Previous clinical studies have shown the safety and efficacy of the traditional Chinese medicinal herbal aqueous extract Chan-Yu-Bao-Yuan-Tang (CYBYT) for the treatment of lung and cervical cancer patients. Used in combination with 5-fluorouracil (5-Fu), CYBYT has been observed to be particularly effective in cancer treatment. Herein, the combined anticancer effect and the underlying mechanisms of 5-Fu and CYBYT in the human lung cancer cell line A549 and the human cervical cancer cell line HeLa were investigated in vitro. The MTT assay, Annexin V-FITC staining and Western blotting were applied to identify cell viability, the stages of apoptosis and the expression of signaling proteins, respectively. The results indicated that CYBYT and 5-Fu, alone or in combination, significantly inhibited proliferation and induced marked apoptosis in A549 and HeLa cells, but had no significant inhibitory effects on normal human IMR-90 fibroblasts. The rate of mid and late apoptosis or necrosis was greater after 5-Fu treatment compared to treatment with CYBYT or the combination of agents; however, the early apoptotic rate showed opposite results. CYBYT and 5-Fu, alone or in combination, up-regulated cleaved caspase-3 expression in a time-dependent manner, with CYBYT being more effective than 5-Fu. Taken together, our data show that the pro-apoptotic activity of the two-drug combination was much stronger than that of CYBYT or 5-Fu alone; CYBYT combined with 5-Fu had synergistic effects at lower concentrations and promoted apoptosis, while the combined treatment also decreased the cytotoxic side effects of 5-Fu.
\end{abstract}

Correspondence to: Dr Yongkui Zhang, Department of Cardiothoracic Surgery, Zhoushan Hospital, 238 Renming North Road, Dinghai, Zhoushan, Zhejiang 316004, P.R. China

E-mail: zengfang20052008@yahoo.com.cn

*Contributed equally

Key words: Chan-Yu-Bao-Yuan-Tang, 5-fluorouracil, apoptosis, proliferation, cancer, caspase-3

\section{Introduction}

Lung cancer is the first and cervical cancer is the third most common malignancy in women worldwide, and the two remain the leading causes of cancer-related death for women in developing countries $(1,2)$. At present, surgery and chemotherapy are the main therapeutic methods used for the treatment of cancer; however, existing chemotherapeutic drugs do not demonstrate ideal curative effects and additionally exhibit numerous undesirable side effects. A combination of multi-therapeutic methods may effectively improve the treatment of lung and cervical cancer patients, minimize their symptoms, reduce the toxicity of conventional chemotherapeutics and prolong their survival time (3).

For the past 40 years, 5 -fluorouracil (5-Fu) has been one of the most frequently used antitumor agents for the treatment of cancer, including cervical, lung and gastric tumors. However, $5-\mathrm{Fu}$ treatment has a high incidence of toxicity in bone marrow, the gastrointestinal tract, the central nervous system and skin, which has prompted efforts to develop derivatives aimed at reducing its adverse effects $(4,5)$. The identification of new anti-cancer drugs with low toxicity and high efficiency that can be used in combination with existing agents, such as 5-Fu, and serve to optimize their efficacy, may result in the development of novel therapeutic methods for the treatment of lung and cervical cancer.

Chan-Yu-Bao-Yuan-Tang (CYBYT), a traditional Chinese medicinal herbal aqueous extract, has been used for many years to treat lung and cervical cancer in China. CYBYT has been demonstrated to inhibit the growth of SPC-A-1 cells by causing cell cycle arrest at the $\mathrm{S}$ phase and inducing apoptosis, while having no significant inhibitory effects on normal human IMR-90 fibroblasts. Moreover, CYBYT was found to up-regulate Bax and cleave caspase-3 protein expression, downregulate $\mathrm{Bcl}-2$ protein expression and release mitochondrial cytochrome $\mathrm{c}$ into the cytosol in a time- and dose-dependent manner (6). Therefore, CYBYT may be an effective anticancer drug candidate with low toxicity to normal cells.

In the present study, we evaluated the effects of $5-\mathrm{Fu}$ combined with CYBYT with regard to their activities against 
lung and cervical cancer in vitro, and investigated the possible mechanisms involved.

\section{Materials and methods}

Chemicals and reagents. 5-Fu was purchased from Shanghai Xudong Haipu Pharmaceutical Co., Ltd. (Shanghai, China). RPMI-1640 medium and fetal calf serum (FCS) were obtained from Gibco BRL (Gaithersburg, MD, USA). The Annexin V-FITC apoptosis detection kit was purchased from Beckman Coulter (Fullerton, CA, USA). Sodium 3-(4, 5-dimethylthizol2-yl)-2,5-diphenyltetrazolium bromide (MTT) and dimethyl sulfoxide (DMSO) were obtained from Beyotime Institute of Biotechnology (Haimen, China). Sodium dodecyl sulfatepolyacrylamide gel electrophoresis (SDS-PAGE) reagents were purchased from Sigma (St. Louis, MO, USA). The protein standard marker was purchased from Shanghai Generay Biotech Co., Ltd. (Shanghai, China). Rabbit antihuman caspase-3 polyclonal antibodies, rabbit anti-human $\beta$-actin polyclonal antibodies and goat anti-rabbit IgG-HRP were purchased from Santa Cruz Biotechnology (Santa Cruz, CA, USA).

CYBYT preparation. CYBYT was prepared as a lyophilized dry powder of hot water extracts from eleven species of medical herbs: Rehmannia root (30 g), radix astragali (60 g), toad skin (18 g), limax (10 g), raw rhizoma arisaematis (15 g), raw pinellia tuberifera tenore (15 g), black nightshade herb (30 g), radix ranunculi ternati (18 g), oldenlandia diffusa $(60 \mathrm{~g})$, bulbus fritillariae thunbergii (30 g) and radix stemonae (30 g). All herbs were provided by Tong Ren Tang Co., Ltd. (Beijing, China). The authenticity of the plants was confirmed by Dr Gang Chen, Experiment Center of TCM, Hubei University of Chinese Medicine. Each prescription (316 g) was decocted three times with 1.51 of boiling distilled water for $1.5 \mathrm{~h}$. Raw rhizoma arisaematis and raw pinellia tuberifera tenore were decocted for $30 \mathrm{~min}$ beforehand. The decoction was filtered, collected, concentrated and lyophilized. The average yield of CYBYT obtained was $19.5 \%$.

Cell culture. Human lung cancer A549 cells, human cervical cancer HeLa cells and normal human fibroblast IMR-90 cells were kindly provided by the Shanghai Institute of Cell Biology, Chinese Academy of Sciences. All cells were maintained in RPMI-1640 media supplemented with 10\% FCS, penicillin $(100 \mathrm{U} / \mathrm{ml})$ and streptomycin $(100 \mathrm{U} / \mathrm{ml})$ at $37^{\circ} \mathrm{C}$ in a humidified atmosphere of $5 \% \mathrm{CO}_{2}$.

Cell proliferation assay. The effects of CYBYT combined with 5-Fu or used alone on cell viability and proliferation were determined using the MTT colorimetric assay. Briefly, cells at the logarithmic phase of growth were plated into 96 -well plates $\left(5 \times 10^{3}\right.$ cells/well). After $24 \mathrm{~h}$ of incubation, A549, HeLa and IMR-90 cells were treated with CYBYT (800, 400, 200, 100, $50,25$ and $12.5 \mu \mathrm{g} / \mathrm{ml})$ and 5-Fu $(64,32,16,8,4,2$ and $1 \mu \mathrm{g} /$ $\mathrm{ml}$ ) for 24 or $48 \mathrm{~h}$, respectively. Subsequently, $20 \mu \mathrm{l}$ MTT [5 $\mathrm{mg} / \mathrm{ml}$ in phosphate-buffered saline (PBS)] was added to each well. After $4 \mathrm{~h}$ of incubation, the MTT solution was removed and replaced with $150 \mu \mathrm{l}$ of DMSO for $10 \mathrm{~min}$ at $37^{\circ} \mathrm{C}$, until the crystals were dissolved. The OD value of each well was measured using a Model 680 microplate reader (Bio-Rad, Hercules, CA, USA) with a test wavelength of $490 \mathrm{~nm}$. The cell inhibitory rate (A value) was expressed as the following equation: $\mathrm{A}=[\mathrm{OD}$ (control) - OD (drug)]/[OD (control) - OD (blank)] x $100 \%$. The concentration of the test substances resulting in a cellular cytotoxicity of the cancer cells of $50 \%$ $\left(\mathrm{IC}_{50}\right)$ was calculated based on the absorbance values.

Evaluation of the combined effect of the agents. The effect of the drug combinations was analyzed using the method of Chou and Talalay $(7,8)$, one of the most commonly used methods for the evaluation of combination effects by medianeffect analysis. In brief, the two drugs were administered at a fixed ratio; the dose of the combination required to produce fractional survival was divided into the component doses D1 and D2 of the drugs CYBYT and 5-Fu, respectively. The combination index (CI) was calculated according to the equation: $\mathrm{CI}=(\mathrm{D} 1 / \mathrm{Dx} 1)+(\mathrm{D} 2 / \mathrm{Dx} 2)+\alpha(\mathrm{D} 1 \mathrm{D} 2) /(\mathrm{Dx} 1 \mathrm{D} \times 2)$, where Dx1 and Dx2 are the concentrations of the drugs CYBYT and $5-\mathrm{Fu}$ when used individually that produce a surviving fraction of $\mathrm{x}$; and D1 and D2 are the individual concentrations of the drugs CYBYT and 5-Fu in a fixed ratio that produce a surviving fraction of $\mathrm{x}$ : $\alpha=1$ or 0 depending on whether the drugs are assumed to be mutually non-exclusive or mutually exclusive, respectively. Since the sigmoidicity of the doseeffect curves for CYBYT and 5-Fu is different, $\alpha=1$ in this study. CI indicates antagonism $(\mathrm{CI}>1)$, additivity $(\mathrm{CI}=1)$ or synergism $(\mathrm{CI}<1)$. The linear correlation coefficient $r$ was generated for each curve to determine the applicability of the data to this method of analysis.

Morphological examination for apoptosis. The cells at logarithmic growth phase were harvested and seeded on 6-well plates at $1 \times 10^{5}$ cells/well. After $24 \mathrm{~h}$ of incubation, A549 and HeLa cells were treated with CYBYT and 5-Fu, alone or in combination, for $48 \mathrm{~h}$, respectively. Morphological changes in the cells before and after treatment were observed under an inverted microscope (Olympus CK-30, Tokyo, Japan).

Quantification of apoptotic cells. Cell apoptosis was assayed by Annexin V and PI staining and analyzed by flow cytometry. The individual and combined apoptotic effects of CYBYT and 5-Fu on the A549 and HeLa cells at $48 \mathrm{~h}$ were respectively detected. After $2 \mathrm{ml}$ of $1 \times 10^{5}$ cells $/ \mathrm{ml}$ were seeded in each well of a 6-well plate and incubated for $24 \mathrm{~h}$, all cells in the suspension and adherent cells were collected. After centrifugation for $5 \mathrm{~min}$ at $500 \mathrm{x} \mathrm{g}$ at $4^{\circ} \mathrm{C}$, the cell samples were washed in icecold PBS. The supernatants were discarded, and the cell pellets were resuspended in ice-cold diluted binding buffer at $5 \times 10^{5}$ to $5 \times 10^{6}$ cells $/ \mathrm{ml}$. Annexin V-FITC solution $(5 \mu \mathrm{l})$ and PI $(2.5 \mu \mathrm{l})$ were added to $100 \mu \mathrm{l}$ of the cell suspension, which was mixed gently and maintained on ice for $10 \mathrm{~min}$ in the dark. Additional ice-cold $1 \mathrm{X}$ binding buffer $(400 \mu \mathrm{l})$ was added to the prepared cell samples, which were mixed gently and analyzed by flow cytometry and with CellQuest software (9).

Western blot analysis. A549 and HeLa cells (2x10 cells/ plate) were exposed to the individual and combined effects of CYBYT and 5-Fu for 24 or $48 \mathrm{~h}$. Then, all cells in the suspension and adherent cells were respectively collected, 
A

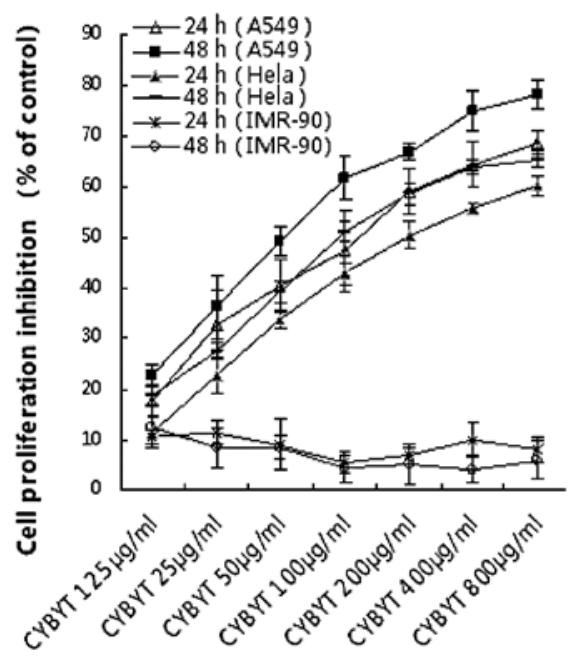

B

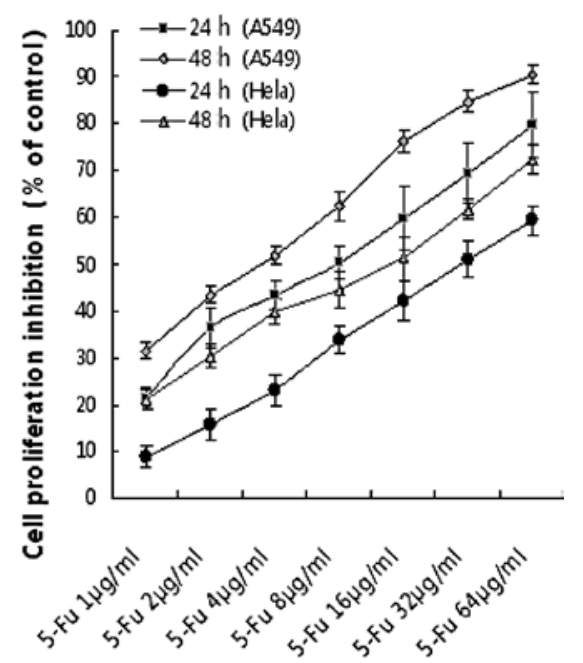

C

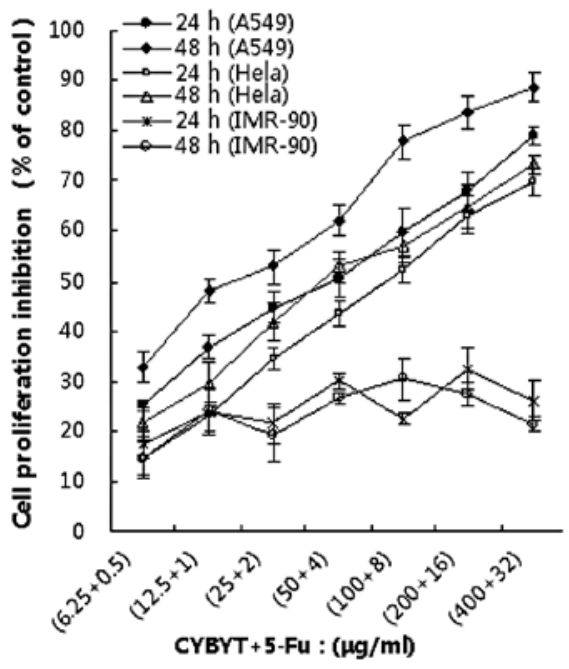

Figure 1. (A) Curve of the growth inhibition rate of A549, HeLa and IMR-90 cells after treatment with CYBYT (800, 400, 200, 100, 50, 25 and $12.5 \mu \mathrm{g} /$ $\mathrm{ml}$ ) for 24 or $48 \mathrm{~h}$. Linear regression equations of A549 cells: $24 \mathrm{~h}: \mathrm{y}=8.4004 \mathrm{x}+13.624, \mathrm{r}=0.9747, \mathrm{IC}_{50} 133.03 \mu \mathrm{g} / \mathrm{ml} ; 48 \mathrm{~h}: \mathrm{y}=9.3501 \mathrm{x}+18.351, \mathrm{r}=0.9581$, $\mathrm{IC}_{50} 69.24 \mu \mathrm{g} / \mathrm{ml}$. Linear regression equations of HeLa cells: $24 \mathrm{~h}: \mathrm{y}=8.1783 \mathrm{x}+6.9303, \mathrm{r}=0.9733, \mathrm{IC}_{50} 253.27 \mu \mathrm{g} / \mathrm{ml} ; 48 \mathrm{~h}: \mathrm{y}=8.3161 \mathrm{x}+13.178, \mathrm{r}=0.9562$, $\mathrm{IC}_{50} 142.78 \mu \mathrm{g} / \mathrm{ml}$. (B) Curve of the growth inhibition rate of A549 and HeLa cells after treatment with 5-Fu (64, 32, 16, 8, 4, 2 and $\left.1 \mu \mathrm{g} / \mathrm{ml}\right)$ for 24 or $48 \mathrm{~h}$. Linear regression equations of A549 cells: $24 \mathrm{~h}: \mathrm{y}=9.1982 \mathrm{x}+14.703, \mathrm{r}=0.991, \mathrm{IC}_{50} 7.35 \mu \mathrm{g} / \mathrm{ml} ; 48 \mathrm{~h}: \mathrm{y}=10.141 \mathrm{x}+22.374, \mathrm{r}=0.9923, \mathrm{IC} 503.45 \mu \mathrm{g} / \mathrm{ml}$ Linear regression equations of HeLa cells: $24 \mathrm{~h}: \mathrm{y}=8.6118 \mathrm{x}-1.0029, \mathrm{r}=0.9978, \mathrm{IC}_{50} 30.76 \mu \mathrm{g} / \mathrm{ml} ; 48 \mathrm{~h}: \mathrm{y}=8.1354 \mathrm{x}+13.351, \mathrm{r}=0.9896, \mathrm{IC} 50$ 12.04 $\mu \mathrm{g} / \mathrm{ml} .(\mathrm{C})$ Combined effects of CYBYT and 5-Fu on A549, HeLa and IMR-90 cells treated with CYBYT (400, 200, 100, 50, 25, 12.5 and 6.25 $\mu \mathrm{g} / \mathrm{ml})$, combined with 5-Fu $(32,16,8,4,2,1$ and $0.5 \mu \mathrm{g} / \mathrm{ml})$ at a constant molar ratio $12.5: 1$ for 24 or $48 \mathrm{~h}$. Linear regression equations of A549 cells: $24 \mathrm{~h}: \mathrm{y}=8.5373 \mathrm{x}+17.828$, $\mathrm{r}=0.9938, \mathrm{IC}_{50} 44.21 \pm 3.54 \mu \mathrm{g} / \mathrm{ml} ; 48 \mathrm{~h}: \mathrm{y}=9.4102 \mathrm{x}+26.048, \mathrm{r}=0.9781, \mathrm{IC}_{50} 19.32 \pm 1.55 \mu \mathrm{g} / \mathrm{ml}$. Linear regression equations of HeLa cells: $24 \mathrm{~h}: \mathrm{y}=9.3994 \mathrm{x}+$ $5.3632, \mathrm{r}=0.9974, \mathrm{IC}_{50} 87.44 \pm 7.00 \mu \mathrm{g} / \mathrm{ml} ; 48 \mathrm{~h}: \mathrm{y}=8.5728 \mathrm{x}+14.357, \mathrm{r}=0.9862, \mathrm{IC}_{50} 57.88 \pm 4.63 \mu \mathrm{g} / \mathrm{ml}$. The percentage of cell proliferation was calculated in comparison to the control, which was considered $100 \%$.

as described above. Aliquots of cell lysates containing $20 \mu \mathrm{g}$ of proteins were separated by $12 \%$ SDS-polyacrylamide gel and transferred to PVDF membranes. The membranes were blocked with TBST buffer containing 5\% skimmed milk, incubated with polyclonal antibodies to caspase-3 (1:500) or $\beta$-actin (1:500) overnight, followed by the addition of horseradish peroxidase-linked anti-rabbit IgG and ECL visualization of the bands. The images were analyzed using the Bio-Rad image detection system (Universal Hood II; Bio-Rad), and quantitation was performed using Quantity One software (Bio-Rad).

Statistical analysis. Data are presented as the means \pm standard deviations of five independent experiments and analyzed by one-way ANOVA and paired t-tests. Otherwise, linear regression and correlation were applied. For all tests, statistical significance was set at the level of $\mathrm{P}<0.05$.

\section{Results}

Effects of 5-Fu or CYBYT on the inhibition of cell viability and the combination index of the two-drug mixture. The inhibition of proliferation by CYBYT (800, 400, 200, 100, 50, 25 and $12.5 \mu \mathrm{g} / \mathrm{ml}$ ) was assessed in A549, HeLa and IMR-90 cells using the MTT assay, respectively, after 24 or $48 \mathrm{~h}$ of CYBYT exposure following a 24-h culture in drug-free medium. As shown in Fig. 1A, the growth of the A549 and HeLa cells was significantly inhibited in a dose- and time-dependent manner. The $\mathrm{IC}_{50}$ values of CYBYT were $133.03 \mu \mathrm{g} / \mathrm{ml}(24 \mathrm{~h})$ and $69.24 \mu \mathrm{g} / \mathrm{ml}(48 \mathrm{~h})$ in the A549 cells, and $253.27 \mu \mathrm{g} / \mathrm{ml}$ (24 h) and $142.78 \mu \mathrm{g} / \mathrm{ml}(48 \mathrm{~h})$ in the HeLa cells. CYBYT or the combination treatment had little effect on normal human IMR-90 fibroblasts after 24 or 48 h of treatment, suggesting that the proliferation inhibitory effects of CYBYT were relatively potent against lung and cervical cancer cells, but not against normal cells when compared at the same concentrations. Additionally, CYBYT combined with 5-Fu maximized the efficacy and minimized the toxicity of 5-Fu (Fig. 1A and C).

The effect of $5-\mathrm{Fu}(64,32,16,8,4,2$ and $1 \mu \mathrm{g} / \mathrm{ml})$ on A549 and HeLa cell viability at 24 or $48 \mathrm{~h}$ was also assessed. Fig. 1B shows that the cell proliferation was effectively inhibited after 24 or $48 \mathrm{~h}$ of 5 -Fu exposure; a linear correlation was found between the cell growth inhibition rate and $5-\mathrm{Fu}$ concentration. For the same concentration of 5-Fu, the cell growth inhibition rate increased with time, while at the same time points, the cell growth inhibition rate also increased with increases in 5-Fu concentration. The $\mathrm{IC}_{50}$ values of $5-\mathrm{Fu}$ on A549 cells were $7.35 \mu \mathrm{g} / \mathrm{ml}(24 \mathrm{~h})$ and $3.45 \mu \mathrm{g} / \mathrm{ml}(48 \mathrm{~h})$, and on HeLa cells, $30.76 \mu \mathrm{g} / \mathrm{ml}(24 \mathrm{~h})$ and $12.04 \mu \mathrm{g} / \mathrm{ml}(48 \mathrm{~h})$.

To investigate the combined effects of CYBYT $(400,200$, $100,50,25,12.5$ and $6.25 \mu \mathrm{g} / \mathrm{ml})$ and $5-\mathrm{Fu}(32,16,8,4,2,1$ and $0.5 \mu \mathrm{g} / \mathrm{ml}$ ) on the growth of A549 and HeLa cells, the cells were exposed for 24 or $48 \mathrm{~h}$ to both drugs concurrently at a fixed molar ratio (CYBYT:5-Fu ratio, 12.5:1). The inhibitory effect on proliferation was also assessed by the MTT assay. The $\mathrm{IC}_{50}$ values of the combined CYBYT and 5-Fu treatment on the A549 cells were $44.21 \pm 3.54 \mu \mathrm{g} / \mathrm{ml}(24 \mathrm{~h})$ and $19.32 \pm 1.55 \mu \mathrm{g} / \mathrm{ml}(48 \mathrm{~h})$, and for HeLa cells $87.44 \pm 7.00 \mu \mathrm{g} / \mathrm{ml}$ $(24 \mathrm{~h})$ and $57.88 \pm 4.63 \mu \mathrm{g} / \mathrm{ml}$ (48 h) (Fig. 1C).

The inhibition rates were next analyzed using the method of Chou and Talalay (7). As shown in Fig. 2, the CI values were $<1$ when the fractions affected were $<0.619$ in A549 cells. 


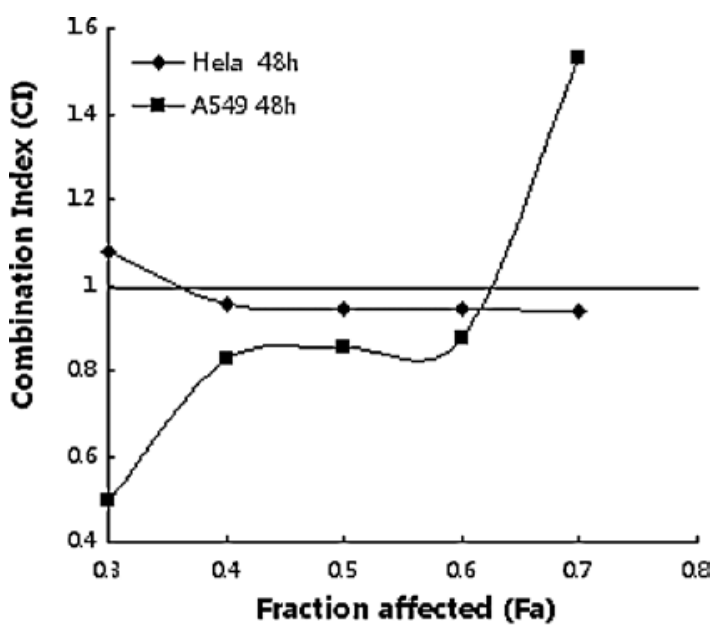

Figure 2. The combined effects of CYBYT $(400,200,100,50,25,12.5$ and $6.25 \mu \mathrm{g} / \mathrm{ml})$ and $5-\mathrm{Fu}(32,16,8,4,2,1$ and $0.5 \mu \mathrm{g} / \mathrm{ml})$ at a constant molar ratio (12.5:1) on A549 and HeLa cells. After a 48-h treatment, the inhibition of proliferation was determined. The combination index $(\mathrm{CI})$ values were determined using a previously described method. $\mathrm{CI}=1$ indicates an additive effect; $\mathrm{CI}<1$ indicates a synergistic effect; $\mathrm{CI}>1$ indicates an antagonistic effect. As shown, the CI values were $<1$ when the fractions affected were $<0.619$ in A549 cells, and $<1$ when the fractions affected were $>0.363$ in HeLa cells.

This indicated that CYBYT and 5-Fu had a synergistic effect on the inhibition of A549 cell proliferation at lower concentrations. The CI values were $<1$ when the fractions affected were $>0.363$ in HeLa cells, indicating that the combination of CYBYT and 5-Fu had a synergistic inhibitory effect on the proliferation of HeLa cells at lower concentrations.

Morphological changes of the cells after individual or combined CYBYT and 5-Fu treatment. In order to examine whether the individual and combined effects of CYBYT and 5-Fu on the growth of A549 and HeLa cells were due to apoptosis, cellular morphological changes characteristic of apoptosis were observed under an inverted microscope. As shown in Fig. 3, cell growth was inhibited after treatment with the drugs, and marked morphological changes were observed, such as dispersed cells, reduced size, altered proportion of nucleus to cytoplasm, membrane blebbing and apoptotic bodies. While the cell membrane was intact, it was shrunken with dark edges. The endochylema produced transparent vacuoles, and the cytoplasm presented radial, lobulated and nail-like protrusions. Buds formed at the membrane, and apoptotic bodies were shed $(10,11)$. More necrotic cells were visible after 5 -Fu treatment as compared to CYBYT treatment. Treatment with the two drugs combined demonstrated a more significant effect exemplified by decreased cell size, larger intercellular space, clearer boundaries, more defined apoptotic morphology and fewer necrotic cells.

Apoptosis induced by individual or combined CYBYT and $5-F u$ treatment. Annexin-V conjugates allow the identification of cell surface changes that occur early during the apoptotic process $(12,13)$. To quantify apoptotic cells after individual or combined treatment with CYBYT and 5-Fu, a biparametric cytofluorimetric analysis was performed using Annexin V-FITC and PI. Annexin V-FITC labels apoptotic
A

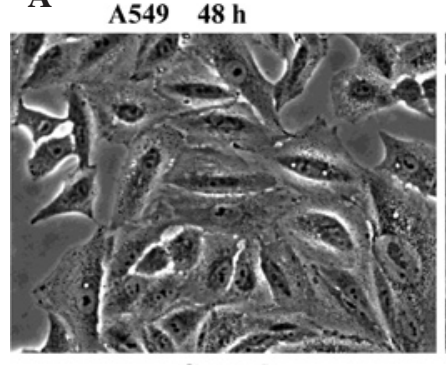

B HeLa $48 \mathrm{~h}$
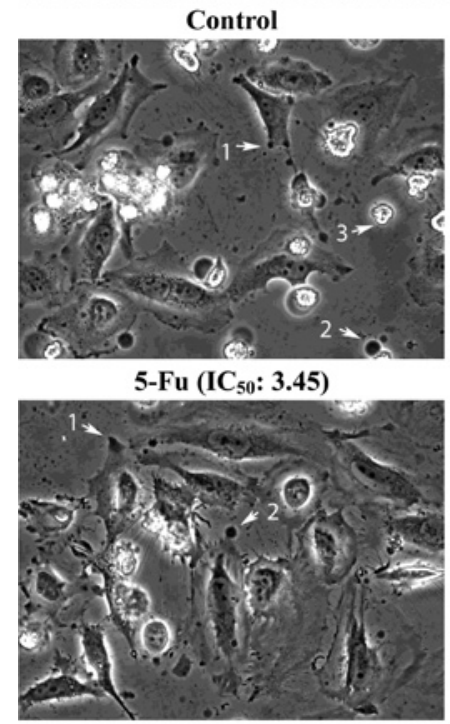

CYBYT $\left(\mathrm{IC}_{50}: 69.24\right)$

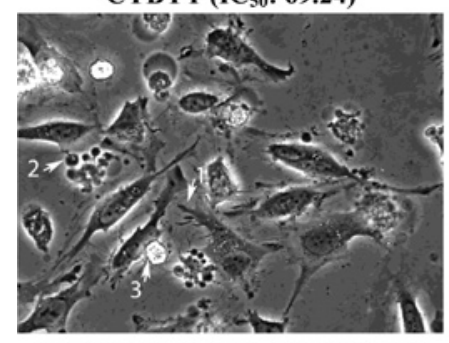

CYBYT+5-Fu $\left(\mathrm{IC}_{50}: \mathbf{1 9 . 3 2 + 1 . 5 5 )}\right.$
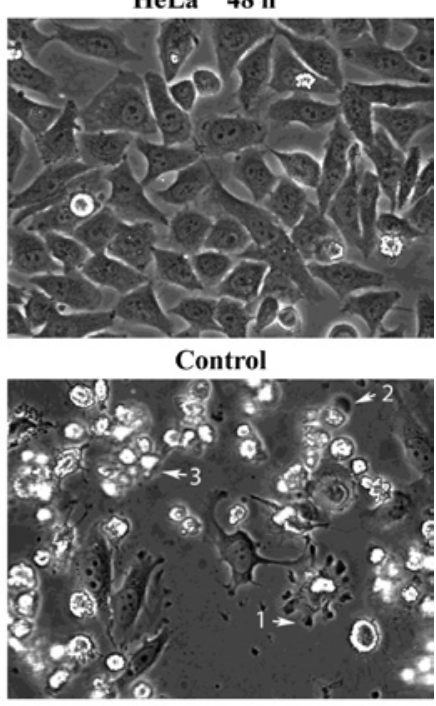

5-Fu $\left(\mathrm{IC}_{50}: 12.04\right)$

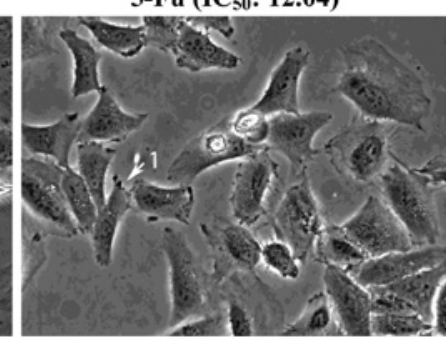

CYBYT ( IC $\left._{50}: 142.78\right)$

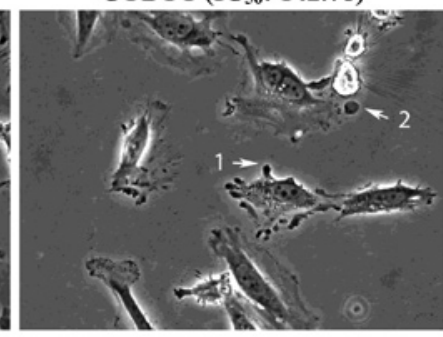

CYBYT+5-Fu $\left(\mathrm{IC}_{50}: \mathbf{5 7 . 8 8 + 4 . 6 3 )}\right.$

Figure 3. Morphological changes in A549 and HeLa cells by inverted light microscopy after treatment with CYBYT and 5-Fu, alone or in combination, for $48 \mathrm{~h}$ (x400). (A) A549 cells. (B) HeLa cells. Arrows indicate: 1, membrane blebbing; 2 , apoptotic bodies; 3 , necrotic cells. $\mathrm{IC}_{50}$ of $5-\mathrm{Fu}: 3.45 \mu \mathrm{g} /$ $\mathrm{ml}$ (A549) and $12.04 \mu \mathrm{g} / \mathrm{ml}$ (HeLa). IC $_{50}$ of CYBYT: $69.24 \mu \mathrm{g} / \mathrm{ml}$ (A549) and $142.78 \mu \mathrm{g} / \mathrm{ml}(\mathrm{HeLa}) . \mathrm{IC}_{50}$ of CYBYT $+5-\mathrm{Fu}: 19.32 \pm 1.55 \mu \mathrm{g} / \mathrm{ml}$ (A549) and $57.88 \pm 4.63 \mu \mathrm{g} / \mathrm{ml}$ (HeLa).

cells, while PI labels mid and late apoptotic or necrotic cells. Representative flow cytometric plots are shown in Fig. 4A and $\mathrm{B}$; the vertical axis indicates the fluorescence intensity of Annexin V-FITC and the horizontal axis, the fluorescence intensity of PI. Accordingly, Annexin $\mathrm{V}^{+} / \mathrm{PI}^{-}$cells were considered early apoptotic cells, Annexin V-/PI- cells were considered to be living cells, Annexin $\mathrm{V}^{-} / \mathrm{PI}^{+}$cells were mechanically injured cells, and Annexin $\mathrm{V}^{+} / \mathrm{PI}^{+}$cells were mid and late apoptotic or necrotic cells. The cells were clearly divided into the above four types.

This study showed that CYBYT and 5-Fu, alone or in combination, inhibited cell proliferation by inducing A549 and HeLa cell apoptosis. Compared to the untreated control, the proportion of the total and early apoptotic rates increased in the A549 and HeLa cells when treated with CYBYT or 
$\mathbf{A}$
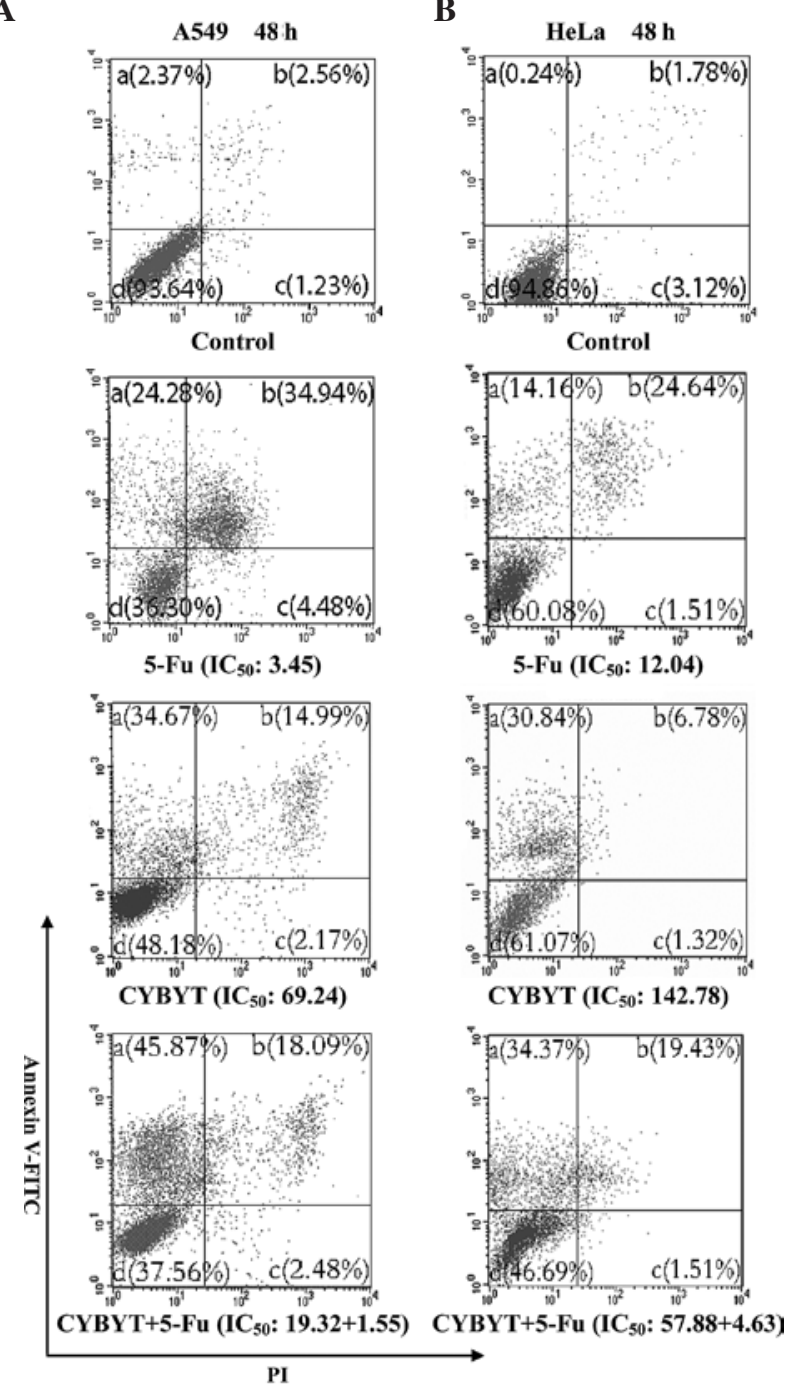

C A549 early apoptotic (a)

A549 mid and late apoptotic or necrotic (b)

Q A549 total apoptotic $(a+b)$

․ Hela early apoptotic (a)

ש Hela mid and late apoptotic or necrotic (b)

ஓ 70 . D Hela total apoptotic $(a+b)$

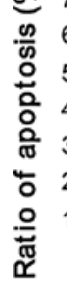
70 . Hela total apoptotic $(a+b)$

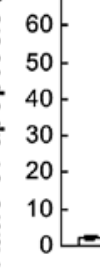

$0 \operatorname{rr}=$

Control

5 -Fu

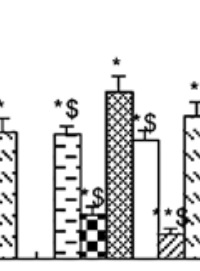

CYBYT

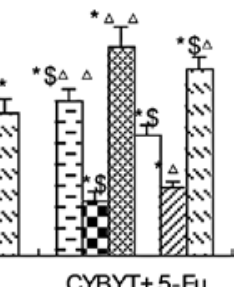

Figure 4. (A) Apoptosis of A549 cells detected by flow cytometry after treatment with CYBYT and 5-Fu, alone or in combination, for $48 \mathrm{~h}$. (B) Apoptosis of HeLa cells detected by flow cytometry after treatment with CYBYT and 5-Fu, alone or in combination, for $48 \mathrm{~h}$. (C) Graphs showing the individual or combined effects of CYBYT and 5-Fu on the apoptotic rate of A549 and HeLa cells detected by Annexin V-FITC/PI double-staining. a, early apoptotic cells; b, mid and late apoptotic or necrotic cells; $a+b$, total apoptotic cells. Data are expressed as the mean $\pm \mathrm{SD}, \mathrm{n}=5$. ${ }^{*} \mathrm{P}<0.01,{ }^{* *} \mathrm{P}<0.05$ compared to the control; ${ }^{\$} \mathrm{P}<0.01$ compared to 5 -Fu treatment; ${ }^{\triangle} \mathrm{P}<0.01$, $\triangle \triangle \mathrm{P}<0.05$ compared to CYBYT treatment.

5-Fu or a combination of the agents. The effects of combined treatment on total apoptosis were stronger than those of CYBYT or 5-Fu treatment alone. Furthermore, the rate of mid and late apoptosis or necrosis was greater after 5-Fu treatment than after CYBYT or combined treatment, while the early apoptotic rate demonstrated opposite results in both cell lines (Tables I and II and Fig. 4).

Western blot detection of the activation of caspase-3. To gain insight into the molecular mechanisms of the induction of apoptosis by CYBYT and 5-Fu, alone or in combination, in the A549 or HeLa cells, caspase-3 protein, a critical executioner of apoptosis, was assessed in the cells by Western blotting. Tables III and IV and Fig. 5 show that after individual or combined CYBYT and 5-Fu treatment for 24 or $48 \mathrm{~h}$, the density of the bands of pro-caspase- 3 (the uncleaved precursors of caspase-3) decreased and levels of cleaved caspase- 3 increased. The ratios of the densitometric measurements of the cleaved/uncleaved caspase- 3 and cleaved caspase- $3 / \beta$-actin gradually increased in a time-dependent manner, indicating that pro-caspase-3 was hydrolyzed and activated with time.

The ratio between cleaved and uncleaved caspase-3 protein expression levels after CYBYT treatment alone was $0.0537 \pm 0.0030(24 \mathrm{~h})$ and $0.6693 \pm 0.0182(48 \mathrm{~h})$ in the A549 cells; both were higher than those of the 5-Fu group. Nevertheless, the combined effect was stronger than that of CYBYT or 5-Fu alone in A549 cells. Under the same conditions, the ratio of cleaved to uncleaved caspase-3 protein expression levels after CYBYT treatment alone was $0.0161 \pm 0.0099(24 \mathrm{~h})$ and $0.1068 \pm 0.0045(48 \mathrm{~h})$ in the HeLa cells, which were also higher than those after 5-Fu treatment, while the combined effect was stronger than that of CYBYT or 5-Fu alone in HeLa cells. Furthermore, a time-dependent shift in the ratio of cleaved/uncleaved caspase- 3 and cleaved caspase-3/ $\beta$-actin was observed after CYBYT and 5-Fu treatment, alone or in combination. Moreover, a similar tendency in the ratios between cleaved caspase- 3 and $\beta$-actin was observed after CYBYT and 5-Fu treatment, alone or in combination, under the same treatment conditions and in the same cells.

\section{Discussion}

We previously reported that CYBYT and 5-Fu both induced apoptosis in human adenocarcinoma cells (6), while the toxic side effect of $5-\mathrm{Fu}$ is an important influencing factor in the treatment of cancer (4). The popularity of traditional herbal medicine used as a complementary or alternative medicine is increasing. Recent evidence also suggests that Chinese medicine alone or combined with chemotherapy reduces toxic side effects, improves the inhibition of chemotherapy, reduces metastasis, and enhances the quality of life and prolongs the lifespan of patients (15).

In the present study, we found that CYBYT and 5-Fu, alone or in combination, effectively inhibited cell proliferation and growth in A549 and HeLa cells in a time-dependent manner, but did not exhibit significant toxic effects in IMR-90 cells, suggesting that CYBYT has selective cytotoxic effects on cancer cells. This selectivity of CYBYT or the combination treatment towards cancer cells may be related to differences in the genomic stability of cancer and normal cells (14). These results suggest that CYBYT warrants evaluation as a novel therapeutic agent with few side effects for the medical treatment of lung and cervical cancer. 
Table I. Effects of each experimental treatment on the apoptotic rate of A549 cells detected by Annexin V-FITC/PI doublestaining (mean $\pm \mathrm{SD}, \mathrm{n}=5$ ).

\section{Quad \% gated (48 h)}

\begin{tabular}{lccc} 
Treatment & a (early apoptotic cells) & $\mathrm{b}$ (mid and late apoptotic or necrotic cells) & $(\mathrm{a}+\mathrm{b})$ (total apoptotic cells) \\
\hline Control & $1.92 \pm 1.02$ & $2.41 \pm 0.93$ & $4.33 \pm 1.86$ \\
5 -Fu & $22.34 \pm 3.04^{\mathrm{a}}$ & $32.48 \pm 2.65^{\mathrm{a}}$ & $54.82 \pm 5.08^{\mathrm{a}}$ \\
CYBYT & $33.64 \pm 2.32^{\mathrm{a}, \mathrm{b}}$ & $11.86 \pm 2.19^{\mathrm{a}, \mathrm{b}}$ & $45.50 \pm 4.06^{\mathrm{a}}$ \\
CYBYT + 5-Fu & $42.06 \pm 3.34^{\mathrm{a}, \mathrm{b}, \mathrm{c}}$ & $14.93 \pm 2.84^{\mathrm{a}, \mathrm{b}}$ & $56.99 \pm 5.42^{\mathrm{a}, \mathrm{c}}$
\end{tabular}

${ }^{\mathrm{a}} \mathrm{P}<0.01$ compared to the control; ${ }^{\mathrm{b}} \mathrm{P}<0.01$ compared to $5-\mathrm{Fu} ;{ }^{\mathrm{c}} \mathrm{P}<0.05$ compared to CYBYT.

Table II. Effects of each experimental treatment on the apoptotic rate of HeLa cells detected by Annexin V-FITC/PI doublestaining (mean $\pm \mathrm{SD}, \mathrm{n}=5)$.

Quad \% gated (48 h)

\begin{tabular}{lccc}
\cline { 2 - 4 } Treatment & $\mathrm{a}$ (early apoptotic cells) & $\mathrm{b}$ (mid and late apoptotic or necrotic cells) & $(\mathrm{a}+\mathrm{b})$ (total apoptotic cells) \\
\hline Control & $1.52 \pm 1.11$ & $1.86 \pm 0.58$ & $3.38 \pm 1.36$ \\
$5-\mathrm{Fu}$ & $12.39 \pm 2.74^{\mathrm{a}}$ & $22.14 \pm 3.50^{\mathrm{a}}$ & $34.52 \pm 3.79^{\mathrm{a}}$ \\
CYBYT & $32.19 \pm 2.71^{\mathrm{a}, \mathrm{c}}$ & $6.45 \pm 1.94^{\mathrm{b}, \mathrm{c}}$ & $38.64 \pm 4.26^{\mathrm{a}}$ \\
CYBYT + 5-Fu & $32.63 \pm 2.92^{\mathrm{a}, \mathrm{c}}$ & $18.38 \pm 1.77^{\mathrm{a}, \mathrm{d}}$ & $51.02 \pm 2.98^{\mathrm{a}, \mathrm{c}, \mathrm{d}}$
\end{tabular}

${ }^{\mathrm{a}} \mathrm{P}<0.01,{ }^{\mathrm{b}} \mathrm{P}<0.05$ compared to the control; ${ }^{\mathrm{P}} \mathrm{P}<0.01$ compared to $5-\mathrm{Fu}$; ${ }^{\mathrm{d}} \mathrm{P}<0.01$ compared to CYBYT.

Table III. Expression of caspase-3-activated fragments in A549 cells detected by Western blotting (mean \pm SD, $\mathrm{n}=5$ ).

\begin{tabular}{lccccc}
\hline & \multicolumn{2}{c}{ A549 $(24 \mathrm{~h})$} & & \multicolumn{2}{c}{ A549 $(48 \mathrm{~h})$} \\
\cline { 2 - 3 } \cline { 5 - 6 } Treatment & Cleaved/pro-caspase-3 & Cleaved caspase-3/ $\beta$-actin & & Cleaved/pro-caspase-3 & Cleaved caspase-3/ $\beta$-actin \\
\hline Control & $0.0192 \pm 0.0045$ & $0.0064 \pm 0.0016$ & & $0.1007 \pm 0.0417$ & $0.0538 \pm 0.0246$ \\
5-Fu & $0.0203 \pm 0.0038$ & $0.0117 \pm 0.0021^{\mathrm{b}}$ & & $0.4758 \pm 0.0085^{\mathrm{a}, \mathrm{e}}$ & $0.3049 \pm 0.0123^{\mathrm{a}, \mathrm{e}}$ \\
CYBYT & $0.0537 \pm 0.0030^{\mathrm{a}, \mathrm{c}}$ & $0.0180 \pm 0.0011^{\mathrm{a}, \mathrm{c}}$ & & $0.6693 \pm 0.0182^{\mathrm{a}, \mathrm{c}, \mathrm{e}}$ & $0.6119 \pm 0.0326^{\mathrm{a}, \mathrm{c}, \mathrm{e}}$ \\
CYBYT+5-Fu & $0.0957 \pm 0.0050^{\mathrm{a}, \mathrm{c}, \mathrm{d}}$ & $0.0191 \pm 0.0007^{\mathrm{a}, \mathrm{c}}$ & & $1.3533 \pm 0.0366^{\mathrm{a}, \mathrm{c}, \mathrm{d}, \mathrm{e}}$ & $0.6405 \pm 0.0291^{\mathrm{a}, \mathrm{c}, \mathrm{e}}$ \\
\hline
\end{tabular}

Comparisons conducted after the same time periods and at different concentrations: ${ }^{a} \mathrm{P}<0.01,{ }^{\mathrm{b}} \mathrm{P}<0.05$ compared to the control; ${ }^{\mathrm{P}} \mathrm{P}<0.01$ compared to 5-Fu; ${ }^{\mathrm{P}}<0.01$ compared to CYBYT. Comparison at the same concentration after different time periods: compared to the 24-h treatment, ${ }^{\mathrm{e}} \mathrm{P}<0.01 . \beta$-actin was used as a control.

Table IV. Expression of caspase-3-activated fragments in HeLa cells detected by Western blotting (mean \pm SD, $\mathrm{n}=5$ ).

\begin{tabular}{lccccc}
\hline & \multicolumn{2}{c}{ HeLa $(24 \mathrm{~h})$} & & \multicolumn{2}{c}{ HeLa $(48 \mathrm{~h})$} \\
\cline { 2 - 3 } \cline { 5 - 6 } Treatment & Cleaved/pro-caspase-3 & Cleaved caspase-3/ $\beta$-actin & & Cleaved/pro-caspase-3 & Cleaved caspase-3/ $\beta$-actin \\
\hline Control & $0.0048 \pm 0.0049$ & $0.0012 \pm 0.0013$ & & $0.0075 \pm 0.0055$ & $0.0070 \pm 0.0052$ \\
5-Fu & $0.0160 \pm 0.0083$ & $0.0030 \pm 0.0016$ & & $0.0889 \pm 0.0024^{\mathrm{a}, \mathrm{f}}$ & $0.0650 \pm 0.0018^{\mathrm{a}, \mathrm{f}}$ \\
CYBYT & $0.0161 \pm 0.0099$ & $0.0070 \pm 0.0041$ & & $0.1068 \pm 0.0045^{\mathrm{a}, \mathrm{b}, \mathrm{f}}$ & $0.0754 \pm 0.0044^{\mathrm{a}, \mathrm{c}, \mathrm{f}}$ \\
CYBYT + 5-Fu & $0.1480 \pm 0.0177^{\mathrm{a}, \mathrm{b}, \mathrm{d}}$ & $0.0775 \pm 0.0073^{\mathrm{a}, \mathrm{b}, \mathrm{d}}$ & & $0.1495 \pm 0.0090^{\mathrm{a}, \mathrm{b}, \mathrm{d}}$ & $0.0856 \pm 0.0019^{\mathrm{a}, \mathrm{b}, \mathrm{e}}$ \\
\hline
\end{tabular}

Comparisons conducted after the same time periods and at different concentrations: ${ }^{\mathrm{P}} \mathrm{P}<0.01$ compared to the control; ${ }^{\mathrm{b}} \mathrm{P}<0.01$, ${ }^{\mathrm{c}} \mathrm{P}<0.05$ compared to $5-\mathrm{Fu}$; ${ }_{\mathrm{d}}^{\mathrm{P}}<0.01,{ }^{\mathrm{e}} \mathrm{P}<0.05$ compared to $\mathrm{CYBYT}$. Comparison at the same concentration after different time periods: compared to the 24-h treatment, ${ }^{\mathrm{P}} \mathrm{P}<0.01 . \beta$-actin was used as a control. 
A
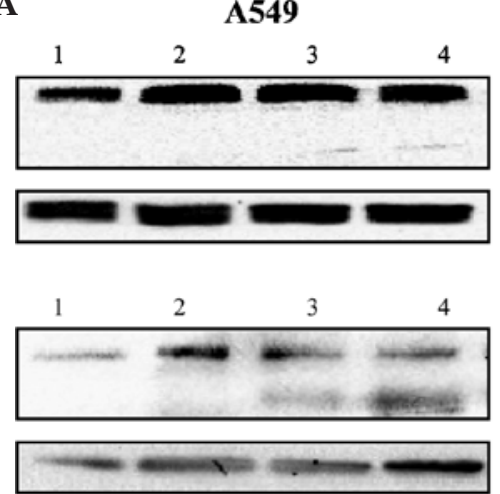

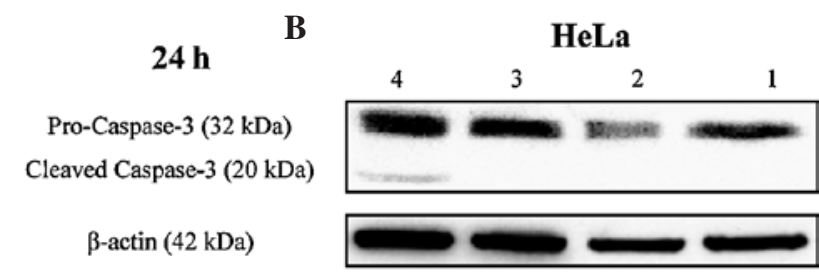

$48 \mathrm{~h}$

Pro-Caspase-3 (32 kDa)

Cleaved Caspase-3 (20 kDa)

$\beta$-actin $(42 \mathrm{kDa})$

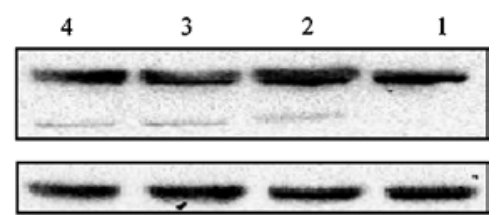

C

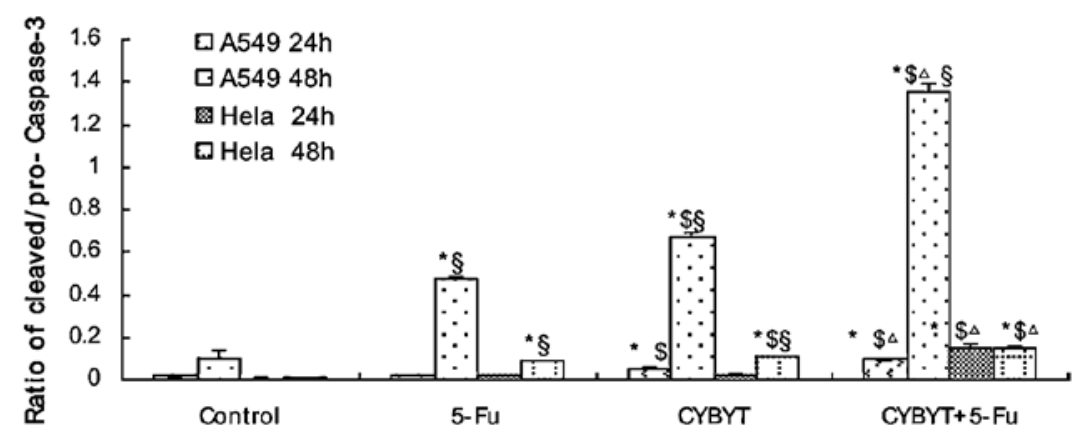

D

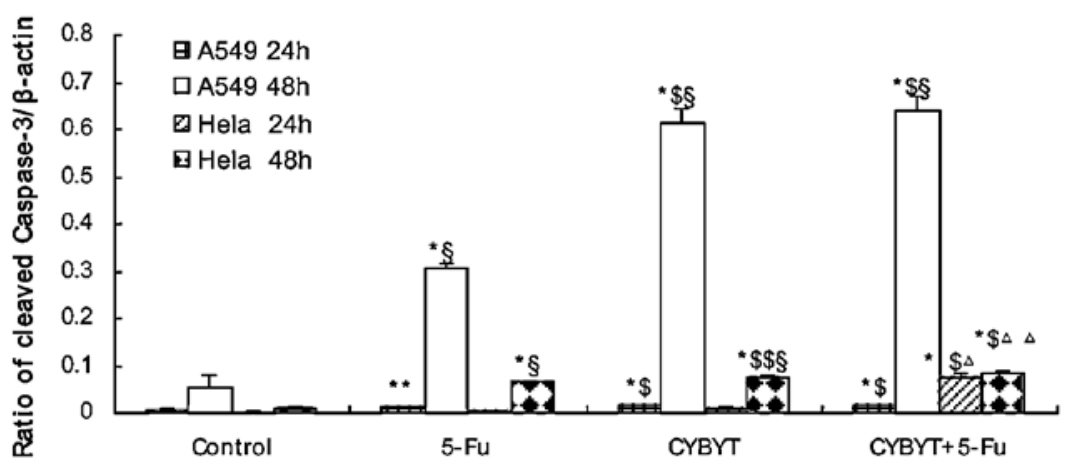

Figure 5. (A) Expression level of cleaved caspase-3 proteins in A549 cells detected by Western blotting after exposure to CYBYT and 5-Fu, alone or in combination, for 24 or $48 \mathrm{~h}$. (B) Expression level of cleaved caspase-3 proteins in HeLa cells detected by Western blotting after exposure to CYBYT and 5-Fu, alone or in combination, for 24 or $48 \mathrm{~h}$. Lane 1, control; lane 2, 5-Fu treatment; lane 3, CYBYT treatment; lane 4, CYBYT + 5-Fu treatment. (C) The protein expression levels of caspase-3-activated fragments were detected in A549 and HeLa cells by Western blotting. $\beta$-actin was used as a control in all histograms Data are expressed as the mean $\pm \mathrm{SD}, \mathrm{n}=5$. Comparisons conducted after the same time periods at different concentrations: " $\mathrm{P}<0.01,{ }^{* * *} \mathrm{P}<0.05$ compared to the control; ${ }^{\$ \mathrm{P}}<0.01,{ }^{\$ \$} \mathrm{P}<0.05$ compared to 5 -Fu; ${ }^{\triangle \mathrm{P}}<0.01,{ }^{\triangle} \triangle \mathrm{P}<0.05$ compared to $\mathrm{CYBYT}$. Comparison at the same concentration after different time periods: $\S \mathrm{P}<0.01$ compared to the 24 -h treatment. $\beta$-actin served as the control.

We also evaluated the drug-drug interaction between CYBYT and 5-Fu using the CI method. Our findings strongly suggest that a combination therapy using CYBYT and 5-Fu may achieve a synergistic effect on lung and cervical cancer. The results obtained were identical to those of previous studies $(16,17)$, which revealed that relatively high concentrations of 5-Fu were required to achieve significant cytotoxic effects against A549 and HeLa cells. These studies evaluated the inhibitory effect of a single herb or its extract on cancer. However, in this study CYBYT was prepared by boiling multiple herbs at a high-temperature, which may create a chemical process to generate more therapeutically effective supermolecular structures. Thus, the CYBYT more closely represented the combinations of herbs used in traditional Chinese medicine and better reflected the actual treatments used in the clinic for individualized therapies, compared to single herbs. The combination of CYBYT and 5-Fu in this study had a synergistic inhibitory effect on the proliferation of A549 or HeLa cells at greatly reduced concentrations, and the two drugs combined also resulted in fewer necrotic cells compared to the 5-Fu treatment alone. Thus, it is conceivable that CYBYT controls and minimizes the side effects of 5-Fu.

CYBYT and 5-Fu, alone or in combination, significantly increased the protein level of cleaved caspase-3, and hydrolyzed and activated pro-caspase-3 in a time-dependent manner. It was further confirmed that 5-Fu induced minimum early apoptosis and caspase-3 activation, while the apoptotic pathway induced by 5 -Fu was consistent with that of previous studies $(16,18)$. Furthermore, the hydrolysis and activation rate for the combination treatment was superior to that of 
the individual treatments. The results of Western blotting for the treatments were consistent with the early apoptosis rate, suggesting that cleaved caspase- 3 is a marker of early apoptosis appearing mostly in early apoptotic cells.

In conclusion, 5-Fu and CYBYT combination treatment suppresses the growth of lung or cervical cancer cells by a synergistic effect with the induction of apoptosis. This in vitro synergistic effect supports the clinical application of a combination chemotherapy protocol to patients with lung or cervical cancer.

\section{Acknowledgements}

This study was supported by a grant from the Administrative Bureau of Traditional Chinese Medicine of Zhejiang Province, China (no. 2008CA113).

\section{References}

1. Aliabadi-Wahle S, Ebersole M, Choe EU, et al: Training in clinical breast examination as part of a general surgery core curriculum. J Cancer Educ 15: 10-13, 2000.

2. Franco EL, Schlecht NF and Saslow D: The epidemiology of cervical cancer. Cancer J 9: 348-359, 2003.

3. Kodera Y, Fujiwara M, Koike M, et al: Chemotherapy as a component of multimodal therapy for gastric carcinoma. World J Gastroenterol 12: 2000-2005, 2006.

4. Cai TB, Tang X, Nagorski J, et al: Synthesis and cytotoxicity of 5-fluorouracil/diazeniumdiolate conjugates. Bioorg Med Chem 11: 4971-4975, 2003.

5. Yamamoto K, Izumi R, Hasegawa K, et al: Adjuvant oral 5-fluorouracil for cervical cancer: Japanese Gynecologic Oncology Group report. Int J Oncol 24: 1175-1179, 2004.

6. Liu XG, Zeng F, Zou SQ, et al: Chan-Yu-Bao-Yuan-Tang induces cell-cycle arrest and apoptosis by means of caspase-3 signaling pathway in lung cancer cells. The Annual Compilation of Papers in Academic Department of Cardiothoracic Surgery of Zhejiang 2: 165-166, 2009.
7. Chou TC and Talalay P: Quantitative analysis of dose-effect relationships: the combined effects of multiple drugs or enzyme inhibitors. Adv Enzyme Regul 22: 27-55, 1984.

8. Takabatake D, Fujita T, Shien T, et al: Tumor inhibitory effect of gefitinib (ZD1839, Iressa) and taxane combination therapy in EGFR-overexpressing breast cancer cell lines (MCF7/ADR MDA-MB-231). Int J Cancer 120: 181-188, 2007.

9. Zhang W and Zhang F: Effects of quercetin on proliferation, apoptosis, adhesion and migration, and invasion of HeLa cells. Eur J Gynaecol Oncol 30: 60-64, 2009.

10. Gerl R and Vaux DL: Apoptosis in the development and treatment of cancer. Carcinogenesis 26: 263-270, 2005.

11. Ghobrial IM, Witzig TE and Adjei AA: Targeting apoptosis pathways in cancer therapy. CA Cancer J Clin 55: 178-194, 2005.

12. Vermes I, Haanen C, Steffens-Nakken H, et al: A novel assay for apoptosis. Flow cytometric detection of phosphatidylserine expression on early apoptotic cells using fluorescein labelled Annexin V. J Immunol Methods 184: 39-51, 1995.

13. Aubry JP, Blaecke A, Lecoanet-Henchoz S, et al: Annexin V used for measuring apoptosis in the early events of cellular cytotoxicity. Cytometry 37: 197-204, 1999.

14. Cao Y, Xia QH, Meng H, et al: Antitumor and synergistic effect of Chinese medicine 'Bushen huayu jiedu recipe' and chemotherapy on transplanted animal hepatocarcinoma. World J Gastroenterol 11: 5218-5220, 2005.

15. Yang $\mathrm{CH}$ and Craise LM: Development of human epithelial cell systems for radiation risk assessment. Adv Space Res 14: 115-120, 1994.

16. Hsu HF, Houng JY, Kuo CF, et al: Glossogin, a novel phenylpropanoid from Glossogyne tenuifolia, induced apoptosis in A549 lung cancer cells. Food Chem Toxicol 46: 3785-3791, 2008.

17. Takara K, Horibe S, Obata Y, et al: Effects of 19 herbal extracts on the sensitivity to paclitaxel or 5-fluorouracil in HeLa cells. Biol Pharm Bull 28: 138-142, 2005.

18. Xiao Z, Xue J, Sowin TJ, et al: A novel mechanism of checkpoint abrogation conferred by Chk1 downregulation. Oncogene 24: 1403-1411, 2005. 